\title{
Influence of blood metabolites and body condition score at parturition on fertility and milk yield in Holstein cows
}

\author{
Influencia de metabolitos sanguíneos y condición corporal al parto sobre la fertilidad y producción de \\ leche de vacas Holstein
}

\begin{abstract}
Influência dos metabólitos sanguíneos e da condição corporal ao nascimento na fertilidade e produção de leite de vacas Holstein
\end{abstract}

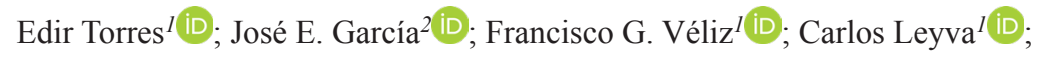

Ulises Macías-Cruz ${ }^{3}$ (iD); Juan D. Hernández-Bustamante ${ }^{l}$ (i); Miguel Mellado ${ }^{2 *}$ (D).

${ }^{1}$ Universidad Autónoma Agraria Antonio Narro, Departamento de Medicina Veterinaria.
${ }^{2}$ Universidad Autónoma Agraria Antonio Narro, Departamento de Nutrición Animal.
${ }^{3}$ Universidad Autónoma de Baja California, Instituto de Ciencias Agrícolas.

To cite this article:

Torres E, García JE, Véliz FG, Leyva C, Macías-Cruz U, Hernández-Bustamante JD, Mellado M. Influence of blood metabolites and body condition score at parturition on fertility and milk yield in Holstein cows. Rev Colomb Cienc Pecu 2021; 34(4): 291-304.

DOI: https://doi.org/10.17533/udea.rccp.v34n4a06

\begin{abstract}
Background: Variables associated with body tissue mobilization place dairy cows at greater risk of reproductive failure. Objective: To investigate the association between blood metabolites and body condition score (BCS) at the beginning of lactation and the reproductive efficiency and milk yield of Holstein cows in a hot environment. Methods: In total, 165 Holstein cows were selected for the study from which blood samples were taken to determine the concentration of various blood metabolites and their association with the reproductive efficiency and milk yield. Results: Cows with serum $\beta$-hydroxybutyrate (BHBA) $\leq 0.8 \mathrm{mmol} / \mathrm{L}$ one week postpartum were 3.3 times more likely to become pregnant at first service, and 2.2 times more likely to become pregnant before $80 \mathrm{~d}$ postpartum than cows with higher serum BHBA levels. The odds (OR 2.7; 95\% CI $1.3-5.4 ; \mathrm{p}<0.01$ ) of a cow getting pregnant at first service were higher in cows with serum creatinine levels higher than 2.0 $\mathrm{mg} / \mathrm{dL}$ one week postpartum than cows with lower blood levels of this metabolite. The BCS at 30 and $60 \mathrm{~d}$ postpartum that predicted pregnancy at first service and pregnancy to all services was 3.0. Blood urea nitrogen $>15 \mathrm{mg} / \mathrm{dL}$, creatinine $<1.8$ $\mathrm{mg} / \mathrm{dL}$, total protein $\leq 5.0 \mathrm{mg} / \mathrm{dL}$ one week postpartum, and $>0.40$ units of BCS loss during the first $30 \mathrm{~d}$ postpartum were critical threshold that predicted the likelihood of 305-d milk yield higher than $10,500 \mathrm{~kg}$. Conclusions: Serum BHBA and creatinine one wk after calving as well as BCS 30 and $60 \mathrm{~d}$ post-calving provided reasonably accurate cut-off screening values to discriminate cows with better reproductive performance and higher 305-d milk yield.
\end{abstract}

Keywords: $\beta$-hydroxybutyrate; creatinine; glucose; blood urea nitrogen; body condition score; cows; dairy cattle; fertility; Holstein; milk yield; pregnancy rate; services per conception.

Received: June 18, 2019; accepted: October 25, 2020

*Corresponding author. Calzada Antonio Narro 1923, Saltillo 24315, México. Tel.: 528444129620. E-mail: mmellbosq@yahoo.com 


\section{Resumen}

Antecedentes: Las variables asociadas a mayor movilización de tejido corporal en vacas lecheras conducen a un mayor riesgo de falla reproductiva. Objetivo: Investigar la asociación entre los metabolitos sanguíneos y condición corporal (BCS) al comienzo de la lactancia y la eficiencia reproductiva y producción de leche de vacas Holstein en un ambiente caluroso. Métodos: En total, se seleccionaron 165 vacas Holstein de las cual se tomaron muestras de sangre para determinar la concentración de varios matabolitos sanguíneos, los cuales se asociaron con el desempeño reproductivo y producción de leche. Resultados: Las vacas con $\beta$-hidroxibutirato (BHBA) en suero $\leq 0,8 \mathrm{mmol} / \mathrm{L}$ una semana postparto tuvieron 3,3 veces más probabilidades de quedar preñadas en los primeros servicios, y 2,2 veces más probabilidades de quedar gestantes antes de los 80 días postparto que las vacas con mayores niveles séricos de BHBA. Las probabilidades (OR 2,7; IC 95\% 1,3-5,4; $<<0,01$ ) de que una vaca se preñara en el primer servicio fueron mayores en vacas con niveles de creatinina en suero sanguíneo superiores a 2,0 mg/dL una semana postparto que las vacas con niveles más bajos de este metabolito en sangre. Una BCS de 3 a los 30 y 60 días postparto fue un buen predictor de la preñez al primer servicio y la gestación considerando todos los servicios. El nitrógeno ureico en sangre $>15 \mathrm{mg} / \mathrm{dL}$, la creatinina $<1,8 \mathrm{mg} / \mathrm{dL}$, la proteína total $\leq 5,0 \mathrm{mg} / \mathrm{dL}$ una semana después del parto y $>0,40$ unidades de pérdida de BCS durante los primeros 30 días postparto fueron los valores críticos para predecir una producción de leche a 305 días superior a $10.500 \mathrm{~kg}$. Conclusiones: El BHBA y la creatinina en suero sanguíneo una semana postparto, así como la BCS 30 y 60 d después del parto, proporcionan valores razonablemente precisos para identificar las vacas que tendrán mejor desempeño reproductivo y mayor producción de leche a 305 días.

Palabras clave: $\beta$-hidroxibutirato; condición corporal; creatinina; fertilidad; ganado vacuno; glucosa; Holstein; nitrógeno ureico; producción de leche; servicios por concepción; tasa de preñez; vacas.

\section{Resumo}

Antecedentes: A maior mobilização do tecido corporal das vacas leiteiras leva a um aumento do risco de falhas reprodutivas. Objetivo: Para investigar a relação entre os metabolitos sanguíneos e condição do corpo (BCS) para o início da lactação e eficiência reprodutiva e produção de leite de vacas Holstein num ambiente quente. Métodos: No total, foram selecionadas 165 vacas da raça Holandesa, das quais foram coletadas amostras de sangue para determinar a concentração de vários metabólitos sanguíneos, associados ao desempenho reprodutivo e à produção de leite das vacas. Resultados: As vacas com $\beta$-hidroxibutirato (BHBA) soro $\leq 0,8 \mathrm{mmol} / \mathrm{L}$ de uma semana após o nascimento foram 3,3 vezes mais probabilidade de engravidar nos primeiros serviços, e 2,2 vezes mais provável que seja grávida antes de 80 dias após o parto do que vacas com níveis séricos de BHBA mais elevados. As probabilidades (OR 2,7, IC de 95\% 1,3-5,4, p<0,01) que uma vaca preñara primeiros serviços vacas foram maiores com níveis mais elevados de creatinina no soro do sangue $>2,0 \mathrm{mg} / \mathrm{dL}$, uma semana pós-parto do que vacas com níveis sanguíneos mais baixos deste metabolito. Um CC de 3 aos 30 e 60 dias pós-parto foi um bom predictor de gravidez no primeiro serviço e gestação, considerando todos os serviços. O azoto de ureia no sangue $>15 \mathrm{mg} / \mathrm{dL}$, creatinina $<1,8 \mathrm{mg} / \mathrm{dL}$ e proteína total, $\leq 5,0 \mathrm{mg} / \mathrm{dL}$ uma semana após o parto e $>0,40$ unidades perda $\mathrm{CC}$ durante os primeiros 30 dias após o nascimento estavam valores críticos que previram produção de leite em 305 dias $>10.500 \mathrm{~kg}$. Conclusões: BHBA e creatinina sérica, uma semana após o parto, bem como CC 30 e $60 \mathrm{~d}$ após o parto, forneceram valores razoavelmente precisos para discriminar vacas com melhor desempenho reprodutivo e maior produção de leite em 305 dias.

Palavras-chave: $\beta$-hidroxibutirato; creatinina; fertilidade; gado leiteiro; glicose; Holstein; nitrogênio da uréia no sangue; pontuação da condição corporal; produção de leite; serviços por concepção; taxa de gravidez; vacas. 


\section{Introduction}

Transition dairy cows enter a state of negative energy balance (NEB) due to increased fatty acids, glucose, and amino acids for colostrum and milk synthesis at parturition (Grummer et al., 2004). This deficit of nutrients is met by mobilizing adipose and muscle tissue in the form of non-esterified fatty acids (NEFA) and amino acids. Therefore, physiological changes occur to support the flux of nutrients to the mammary gland at the expense of other body tissues (Roche et al., 2017). The restricted availability of nutrients, in association with increased energy demand for milk synthesis, leads to modifications in many metabolic pathways and impairment of the finely tuned inter-relation between energy metabolism and reproductive function. Although these changes are normal adaptive processes in high-yielding cows, when cows fail to adjust to this metabolic challenge the resulting NEB adversely affects the reproductive potential (Butler, 2003; Wathes et al., 2007a) even months later (Leroy et al., 2008), as well as milk yield (Ospina et al., 2010). These metabolic and endocrinological changes associated with reduced reproductive performance are attributed, in part, to a suboptimal follicular environment and reduced developmental competence of the oocyte and subsequent embryo (Ashworth et al., 2009; Van Hoeck et al., 2014).

Additionally, mobilization of muscle and fat during early lactation results in deteriorating body energy reserves that is reflected in the cows' metabolic and hormone profiles, such as reduced blood glucose concentrations, increased levels of $\beta$-hydroxybutyrate (BHBA) and non-esterified fatty acids (NEFAs) (Pires et al., 2013). Body condition score (BCS) is also readily affected by the mobilization of body energy reserves, and its assessment is a physical indicator of negative energy balance. These reduced body energy reserves at calving in high-yielding dairy cows may interfere with conception and maintenance of pregnancy in cattle (Santos et al., 2009; Gomez et al., 2018), as well as milk yield (Roche et al., 2009). Given that, in dairy cows, reproductive function and metabolism are reciprocally regulated and tightly connected, blood metabolites are interlinked and provide a tool to assess the physiological state and to assist in the identification of possible biomarkers for fertility research (Oikonomou et al., 2008; Garverick et al., 2013). Blood metabolites can be used objectively, reliably and routinely to assess the nutritional status of cows.

The objectives of this study were to determine the association between serum metabolites (indicative of body energy reserves) and BCS during the first week of lactation on various reproductive variables and milk yield of contemporary high-yielding dairy cows in a hot environment.

\section{Materials and Methods}

\section{Ethical considerations}

Animals were cared for and handled following the Guide for Care and Use of Agricultural Animals in Agricultural Research and Teaching (FASS, 2010).

\section{Study herd, housing, and feeding}

One hundred and eighty-eight Holstein cows were recruited from an intensive commercial 2,500 Holstein cow farm in northern Mexico (25 ${ }^{\circ}$ $\left.31^{\prime} 4^{\prime \prime} \mathrm{N}, 103^{\circ} 13^{\prime} 42^{\prime \prime} \mathrm{W}\right)$. The farm is located in a zone characterized by high daytime temperatures in spring, summer and fall (around $40^{\circ} \mathrm{C}$ ) and intense solar radiation (mean temperaturehumidity index $=82.0$; range 69.8 to 89.0 ) with an average annual precipitation of $230 \mathrm{~mm}$ and an elevation of $1140 \mathrm{~m}$. A total of 23 cows were destined for culling during the insemination period, therefore 165 cows remained in the trial. The criteria used to choose these cows were based on pluriparous cows with four functional quarters, with $>9,000 \mathrm{~kg} 305$-day lactation yields in their previous lactation and with no clinical metabolic diseases.

The cows were 2 to 4 lactations with a BCS ranging between 2.75 and 4.0 at calving (5-point scale; Roche et al., 2009). Cows were followed for an entire lactation (305 days in milk) and were 
fed the same diet as a total mixed ration (TMR) formulated to meet or exceed the predicted requirements of nutrients of a lactating Holstein cow yielding $40 \mathrm{~kg}$ milk/day and $640 \mathrm{~kg}$ of body weight (BW; NRC, 2001). The TMR consisted of $50 \%$ forage and $50 \%$ concentrate for ad libitum intake and daily feed refusal of approximately $8 \%$ of that offered. Diets were formulated to provide at least $1.62 \mathrm{Mcal} / \mathrm{kg} \mathrm{NEL}$ and contained $18 \%$ crude protein.

The cows were housed in large, open-air, dirtfloor pens with metal roofs scattered over the pens and the feeding area, with fans and sprinklers for forced evaporative cooling during warm weather. Cows had unlimited access to fresh water and were scored for BCS at calving, 30, and 60 days postpartum.

\section{Blood sampling and plasma metabolic profile}

A total of 165 blood samples were obtained once during the first wk postpartum from the coccygeal vessels into a $10 \mathrm{~mL}$ evacuated sterile tubes coated with a coagulant (Vacutainer, Becton Dickinson, Franklin Lakes, NJ, USA) connected to a $2.5 \mathrm{~cm} 20-\mathrm{G}$ needle. The tubes were kept chilled at $4{ }^{\circ} \mathrm{C}$ in a cooler and allowed to clot in an upright position for $30 \mathrm{~min}$ to $1 \mathrm{~h}$ before centrifuged at $1200 \times g$ for $20 \mathrm{~min}$ at $4{ }^{\circ} \mathrm{C}$. Blood serum was separated and stored at $-20^{\circ} \mathrm{C}$ within $6 \mathrm{~h}$ of collection in $2 \mathrm{~mL}$ vials until further use.

Immediately after sample collection, an aliquot of blood was removed from the vacutainer using a syringe and entered into a hand-held meter (Precision Xtra BHBA test, Abbott Laboratories, Abbott Park, IL) to determine blood BHBA at cow side. Serum metabolites were determined using spectrophotometric methods (Coleman Junior II, Perkin Elmer Waltham, MA, USA). Serum total protein (TP) concentration was determined with a kit based on the bicinchoninic acid reagent, with bovine serum albumin as a protein standard (Pierce Chemical, Rockford, IL, USA). Serum glucose was assayed with kit 115-A, based on glucose oxidase. Urea was quantified using kit 640-A, based on urease (Sigma-Aldrich Co., St. Louis, MO, USA). Creatinine was measured in serum using the QuantiChromTM Creatinine Assay Kit (DICT-500; BioAssay Systems, Hayward, CA, USA). Serum cholesterol was determined using the EnzyChromTM cholesterol assay kit (ECCH100; BioAssay Systems; Hayward, CA, USA). A commercial kit was used for the determination of non-esterified fatty acids (NEFA) concentrations (Wako Diagnostics, Mountain View, USA). Alkaline phosphatase activity -an indicator of liver health and bone metabolism disturbances- was estimated using an automatic analyzer (Hitachi 912 chemistry analyzer, Ramsey, MN, USA).

\section{Reproductive management and measurements}

The cows were vaccinated (pre-and postbreeding; annual vaccination thereafter) against diseases that affect reproductive performance, such as infectious bovine rhinotracheitis, bovine viral diarrhea, bovine respiratory syncytial virus, and para-influenza (CattleMaster Gold FP5 ${ }^{\circledR}$, Zoetis, Mexico D.F., Mexico). Cows were vaccinated twice a year against leptospirosis (pentavalent leptospiral vaccine; Leptavoid-H®; Merck Sharp Dohme Corp., Mexico, D.F.) Also, all cows were annually tested for bovine tuberculosis and vaccinated against brucellosis (strain RB51; BRUCEL $\AA$, PISA laboratories, Santa Catarina, Mexico).

Reproductive management consisted of estrus synchronization with two injections of $25 \mathrm{mg} \mathrm{PGF}_{2 \alpha}$ (Lutalyse $\mathrm{R}$, Pharmacia Animal Health, Kalamazoo, MI, USA) given 14 days apart starting at $33 \pm 3$ days in milk (DIM). All cows were served using artificial insemination. Cows not pregnant at first service were observed for signs of estrus from 0700 to $0800 \mathrm{~h}$ and from 1700 to $1800 \mathrm{~h}$ each day. Cows were inseminated by experienced AI technicians following the standard a.m./p.m. rule. Pregnancy diagnosis was carried out by the same veterinarian throughout the study period by rectal palpation of the uterus between 43 and $46 \mathrm{~d}$ post-insemination and was reconfirmed at 170-180 days of pregnancy. Measures of reproductive performance were first-service conception rate (CR), pregnancy before $80 \mathrm{~d}$ postpartum, pregnancy rate to all services, and services per conception. At calving, 
retained placenta was treated within $24 \mathrm{~h}$ after parturition. All cows were monitored clinically during 40 DIM for metritis and endometritis and treated accordingly.

\section{Milking management and recordings}

The cows were milked thrice daily (04:00, 12:00, and 20:00 hours), and the annual rolling herd average milk yield was about $11,500 \mathrm{~kg}$ throughout the study. Test-day records for milk yield were obtained every day directly in the farm by the management software Afifarm, version 5.2 (S.A.E. Afikim, Israel). This information was imported into the herd database which provided an estimate of 305-day milk yield for each cow.

\section{Statistical analyses}

A multivariable logistic regression model was fitted with reproductive responses and 305-d milk yield as dependent variables (PROC LOGISTIC of SAS software, version 9.4; SAS Inst., Inc., Cary, NC, USA; 2016). Serum glucose, creatinine, TP, blood urea nitrogen (BUN), NEFA, BHBA, alkaline phosphatase, BCS at 0,30 and $60 \mathrm{~d}$ postcalving and BCS change from calving to 30 or 60 $\mathrm{d}$ post-calving and all biologically plausible 2-way interactions were evaluated as initial explanatory variables in the removal model. These values were treated as categorical variables and were classified into two groups using their means as a dividing point. A stepwise backward selection process was used to construct the final models taking $p<0.15$ for retention of a variable in the model. The variables lactation number and month of calving were forced into the model as covariates. Serum metabolites and BCS as predicting tools for reproductive performance and milk yield were analyzed with receiver operator characteristics (ROC) curves by using PROC LOGISTIC of SAS. Sensitivity (Se) was the proportion of animals that were above a given threshold for a particular trait, and specificity ( $\mathrm{Sp}$ ) was the proportion of animals that were below a given threshold for that trait. The critical threshold was the point on the ROC curve that had the highest combined Se and Sp. To assess and compare the predicting accuracy of serum metabolites and BCS for discriminating cows with better reproductive performance and higher milk yield potential, the areas under the curves (AUC) were determined. AnAUC of $>0.9$ is representative of an ideal test, whereas 0.5 indicates a test of no diagnostic value.

Odds ratios (OR) were modeled with PROC GENMOD, with a Poisson distribution, a log link function, and a $p$-scale option for overdispersion adjustment. In all analyses, results were considered significant at $\mathrm{p}<0.05$.

\section{Results}

There was a significant association between blood BHBA concentration within the first week after calving and first-service pregnancy rate. Cows with serum BHBA levels $\leq 0.8 \mathrm{mmol} / \mathrm{L}$ about one-week post-calving were three times more likely to become pregnant at first service than were cows with higher levels of this metabolite (Table 1).

Likewise, cows with serum creatinine levels $\geq 2.0 \mathrm{mg} / \mathrm{dL}$ had 2.7 times greater chance of becoming pregnant at first service than cows with serum creatinine levels $\leq 2.0 \mathrm{mg} / \mathrm{dL}$ at the beginning of lactation. Cows experiencing a lower reduction in BCS ( $\leq 0.41$ units) from 30 to $60 \mathrm{~d}$ postpartum were 2.5 times more likely to become pregnant at first breeding than cows losing more BCS postpartum.

The critical thresholds of serum BHBA for predicting pregnancy at first service was 0.80 $\mathrm{mmol} / \mathrm{L}$ (area under the curve; AUC, 0.69) within the first week postpartum, $1.8 \mathrm{mg} / \mathrm{dL}$ for creatinine (AUC, 0.61) and 3.0 (AUC, 0.61) for $\mathrm{BCS}$ at 30 and $60 \mathrm{~d}$ postpartum.

As shown in Table 2, both BCS at 30 and $60 \mathrm{~d}$ postpartum were the only variables significantly associated with conception rate to all services. $\mathrm{BCS}$ at 30 and $60 \mathrm{~d}$ postpartum were equally good predictors of pregnancy potential to all services (AUCs 0.64 and 0.66, respectively; $\mathrm{p}<0.01)$. The percentage of cows pregnant with more than two services, grouped by serum metabolite concentrations one-week postpartum are shown in Table 3. 
Table 1. Associations of postpartum serum $\beta$-hydroxybutyrate and creatinine concentrations within one week after calving and body condition score at 30 and $60 \mathrm{~d}$ post-calving with the risk of first-service pregnancy rate (FSCR) in high-yielding Holstein cows $(\mathrm{n}=165)$ in a hot environment. Only significant variables are presented.

\begin{tabular}{|c|c|c|c|c|c|c|c|}
\hline $\begin{array}{l}\text { Variables and area under the } \\
\text { curve (AUC) }\end{array}$ & FSCR (\%) & $\begin{array}{l}\text { Odds ratio } \\
\text { (OR) }\end{array}$ & $\begin{array}{l}\text { OR } 95 \% \\
\text { CI }\end{array}$ & $\mathbf{p}$ & Cutpoint $^{1}$ & $\begin{array}{l}\text { Sen }^{2} \\
(\%)\end{array}$ & $\begin{array}{c}\text { Spec }^{3} \\
(\%)\end{array}$ \\
\hline$\beta$-hydroxybutyrate, $\mathrm{mmol} / \mathrm{L}$ & & & & & $0.80 \mathrm{mmol} / \mathrm{L}$ & 71 & 33 \\
\hline $\mathrm{AUC}=0.69$ & $18.8(15 / 80)$ & Referent & & & & & \\
\hline$\leq 0.8$ & $43.5(37 / 85)$ & 3.3 & $1.5-6.7$ & & & & \\
\hline Creatinine, $\mathrm{mg} / \mathrm{dL}$ & & & & 0.001 & $1.8 \mathrm{mg} / \mathrm{dL}$ & 63 & 43 \\
\hline$\leq 2.0 \quad \mathrm{AUC}=0.61$ & $20.5(17 / 83)$ & Referent & $1.3-5.4$ & & & & \\
\hline$\geq 2.0$ & $41.5(34 / 82)$ & 2.7 & & & & & \\
\hline BCS 30-d postpartum & & & & 0.02 & 3.0 units & & \\
\hline$\leq 3.2 \quad \mathrm{AUC}=0.61$ & $22.2(18 / 81)$ & Referent & & & & 57 & 35 \\
\hline$\geq 3.2$ & $39.2(33 / 84)$ & 2.2 & $1.1-4.4$ & & & & \\
\hline BCS 60-d postpartum & & & & 0.004 & 3.0 units & & \\
\hline$\leq 3.2 \quad$ AUC $=0.60$ & $20.5(17 / 83)$ & Referent & & & & 60 & 33 \\
\hline$\geq 3.2$ & $41.5(34 / 82)$ & 2.8 & $1.4-5.7$ & & & & \\
\hline BCS difference $0-30 \mathrm{~d}$ & & & & 0.01 & 0.50 units & 63 & 43 \\
\hline$\geq 0.41 \quad$ AUC $=0.65$ & $22.5(20 / 89)$ & Referent & & & & & \\
\hline$\leq 0.41$ & $42.1(32 / 76)$ & 2.5 & $1.2-5.0$ & & & & \\
\hline
\end{tabular}

$\mathrm{AUC}=$ area under the ROC (receiver operating characteristic) curve; $\mathrm{BCS}=$ Body condition score.

${ }^{1}$ Cutpoint $=$ herd alarm level where a reduced probability of first-service conception rate exists based on serum metabolite concentration and body condition score in transition cows. ${ }^{2} \mathrm{Sen}=$ Epidemiologic sensitivity from a receiver operating characteristic curve ${ }^{3} \mathrm{Spec}=$ Epidemiologic specificity from a receiver operating characteristic curve.

Table 2. Associations of body condition score (BCS) at 30 and 60 days post-calving with the risk of pregnancy rate $(P R)$ to all services in high-yielding Holstein cows $(n=165)$ in a hot environment. Only significant variables are presented.

\begin{tabular}{|c|c|c|c|c|c|c|c|}
\hline $\begin{array}{l}\text { Variables and area under the } \\
\text { curve (AUC) }\end{array}$ & $\begin{array}{l}\text { PR to all } \\
\text { services }\end{array}$ & $\begin{array}{l}\text { Odds ratio } \\
\text { (OR) }\end{array}$ & $\begin{array}{l}\text { OR } 95 \% \\
\text { CI }\end{array}$ & $\mathbf{p}$ & Cutpoint $^{1}$ & $\begin{array}{l}\text { Sen }^{2} \\
(\%)\end{array}$ & $\begin{array}{c}\text { Spec }^{3} \\
(\%)\end{array}$ \\
\hline BCS $30 \mathrm{~d}$ postpartum & & & & 0.0489 & 3.0 units & 57 & 35 \\
\hline$\leq 3.2 \quad$ AUC $=0.64$ & $76.5(62 / 81)$ & Referent & & & & & \\
\hline$\geq 3.2$ & $89.2(75 / 84)$ & 2.3 & $1.0-5.2$ & & & & \\
\hline BCS $60 \mathrm{~d}$ postpartum & & & & 0.0270 & 3.0 units & 60 & 33 \\
\hline$\leq 3.2 \quad \mathrm{AUC}=0.66$ & $76.2(64 / 84)$ & Referent & & & & & \\
\hline$\geq 3.2$ & $90.1(73 / 81)$ & 2.6 & $1.1-6.0$ & & & & \\
\hline
\end{tabular}

${ }^{1}$ Cutpoint $=$ herd alarm level where an increased probability of non-pregnancy to all services exists based on body condition score in transition cows.

${ }^{2} \mathrm{Sen}=$ Epidemiologic sensitivity from a receiver operating characteristic curve.

${ }^{3} \mathrm{Spec}=$ Epidemiologic specificity from a receiver operating characteristic curve.

Prediction threshold for less than two services per pregnancy was $\leq 0.80 \mathrm{mmol} / \mathrm{LBHBH}$ one week postpartum. Cows with serum glucose $\leq 70 \mathrm{mg} / \mathrm{dL}$ were 1.9 times more likely to require more than two services to become pregnant, relative to cows with higher blood glucose one week postpartum. 
Table 3. Associations of postpartum serum metabolite concentrations one week after calving with the risk of services per conception greater than two $(\mathrm{S} / \mathrm{C}>2)$ in high-yielding Holstein cows $(n=165)$ in a hot environment. Only significant variables are presented.

\begin{tabular}{|c|c|c|c|c|c|c|c|}
\hline $\begin{array}{l}\text { Variables and area under the } \\
\text { curve (AUC) }\end{array}$ & $\begin{array}{l}\text { Percentage } \\
(\mathrm{S} / \mathrm{C}>\mathbf{2})\end{array}$ & $\begin{array}{l}\text { Odds ratio } \\
\text { (OR) }\end{array}$ & $\begin{array}{l}\text { OR 95\% } \\
\text { CI }\end{array}$ & $\mathbf{p}$ & Cutpoint $^{1}$ & $\begin{array}{l}\text { Sen }^{2} \\
(\%)\end{array}$ & $\begin{array}{l}\text { Spec }^{3} \\
(\%)\end{array}$ \\
\hline$\beta$-hydroxybutyrate, $\mathrm{mmol} / \mathrm{L}$ & & & & 0.01 & $0.80 \mathrm{mmol} / \mathrm{L}$ & 59 & 38 \\
\hline$\leq 0.8 \quad$ AUC $=64$ & $32.0(26 / 81)$ & Referent & & & & & \\
\hline$\geq 0.8$ & $52.3(44 / 84)$ & 2.3 & $1.2-4.3$ & & & & \\
\hline Glucose, $\mathrm{mg} / \mathrm{dL}$ & & & & 0.04 & $67.0 \mathrm{mg} / \mathrm{dL}$ & 56 & 46 \\
\hline$\geq 70 \quad$ AUC $=61$ & $32.5(26 / 80)$ & Referent & & & & & \\
\hline$\leq 70$ & $48.2(41 / 85)$ & 1.9 & $1.1-3.6$ & & & & \\
\hline Creatinine, mg/dL & & & & 0.001 & $2.0 \mathrm{mg} / \mathrm{dL}$ & 60 & 34 \\
\hline$\geq 2.0 \quad$ AUC $=64$ & $27.5(22 / 80)$ & Referent & & & & & \\
\hline$\leq 2.0$ & $52.9(45 / 85)$ & 3.0 & $1.5-5.6$ & & & & \\
\hline Total proteins, mg/dL & & & & 0.01 & $5.4 \mathrm{mg} / \mathrm{dL}$ & 62 & 38 \\
\hline$\leq 5.0 \quad$ AUC $=58$ & $30.8(24 / 78)$ & Referent & & & & & \\
\hline$\geq 5.0$ & $64.2(43 / 87)$ & 2.2 & $1.2-4.2$ & & & & \\
\hline
\end{tabular}

$\mathrm{AUC}=$ area under the $\mathrm{ROC}$ (receiver operating characteristic) curve.

${ }^{1}$ Cutpoint $=$ herd alarm level where an increased probability of more than two services per pregnancy exists based on serum metabolite concentration in transition cows.

${ }^{2}$ Sen $=$ Epidemiologic sensitivity from a receiver operating characteristic curve.

${ }^{3} \mathrm{Spec}=$ Epidemiologic specificity from a receiver operating characteristic curve.

Cows with serum levels $\geq 5.0 \mathrm{mg} / \mathrm{dL}$ TP had greater odds of requiring more than two services to become pregnant than cows with lower serum levels of this metabolite. Both serum BHBA and creatinine were better predictors of pregnancy with 2 or fewer services (AUCs 0.64 for both serum metabolites; $\mathrm{p}<0.01$ ) than other serum metabolites measured early in lactation.
Odds ratios and corresponding confidence intervals for variables associated with pregnancy before $80 \mathrm{~d}$ postpartum are presented in Table 4 . The only factor associated with pregnancy before $80 \mathrm{~d}$ postpartum was serum levels of BHBA $(p<0.05)$. Data showed that a cutoff point of 0.81 $\mathrm{mmol} / \mathrm{L}$ serum BHBA one-week post-calving could differentiate between cows conceiving by 80 days postpartum.

Table 4. Associations of postpartum serum $\beta$-hydroxybutyrate one week after calving with the risk of pregnancy before 80 days $(\mathrm{d})$ post-partum $(\mathrm{pp})$ in high-yielding Holstein cows $(\mathrm{n}=165)$ in a hot environment. Only significant variables are presented.

\begin{tabular}{|c|c|c|c|c|c|c|c|}
\hline $\begin{array}{l}\text { Variables and area under the } \\
\text { curve (AUC) }\end{array}$ & $\begin{array}{l}\text { Pregnancy (\%) } \\
<\mathbf{8 0} \text { d pp }\end{array}$ & $\begin{array}{l}\text { Odds ratio } \\
\text { (OR) }\end{array}$ & $\begin{array}{c}\text { OR 95\% } \\
\text { CI }\end{array}$ & $\mathbf{p}$ & Cutpoint $^{1}$ & $\begin{array}{l}\text { Sen }^{2} \\
(\%)\end{array}$ & $\begin{array}{c}\text { Spec }^{3} \\
(\%)\end{array}$ \\
\hline$\beta$-hydroxibutirate, $\mathrm{mmol} / \mathrm{L}$ & & & & 0.008 & $0.81 \mathrm{mmol} / \mathrm{L}$ & 69 & 39 \\
\hline$\geq 0.8 \quad \mathrm{AUC}=.66$ & $35.9(29 / 83)$ & Referent & & & & & \\
\hline$\leq 0.8$ & $54.9(45 / 82)$ & 2.2 & $1.2-3.9$ & & & & \\
\hline
\end{tabular}

$\mathrm{AUC}=$ area under the ROC (receiver operating characteristic) curve.

${ }^{1}$ Cutpoint $=$ herd alarm level where a reduced probability of pregnancy before 80 days post-calving exists based on serum metabolite concentration in transition cows.

${ }^{2} \mathrm{Sen}=$ Epidemiologic sensitivity from a receiver operating characteristic curve.

${ }^{3} \mathrm{Spec}=$ Epidemiologic specificity from a receiver operating characteristic curve. 
Cows with serum BUN levels $\geq 15 \mathrm{mg} /$ $\mathrm{dL}$ one week postpartum were 2.0 times more likely to produce $>10,500 \mathrm{~kg}$ in $305 \mathrm{~d}$ lactations compared to herd mates with lower levels of this metabolite (Table 5). The threshold value had a significant effect $(\mathrm{p}<0.01)$ in discriminating cows with less or more than $10,500 \mathrm{~kg}$ of milk yield in $305 \mathrm{~d}(\mathrm{AUC}=0.60)$. The AUC for the groups with serum creatinine higher or lower than $2.0 \mathrm{mg} / \mathrm{dL}$ creatinine was $0.66(\mathrm{p}<0.01)$ with an optimal prediction threshold for 305 d lactations $>10,500 \mathrm{~kg}$ of $1.8 \mathrm{mmol} / \mathrm{L}$ of this metabolite. Higher BCS change at 30-d postpartum had higher odds of 305-d milk yield greater than $10,500 \mathrm{~kg}$. Compared to cows with serum total proteins $\geq 5.0 \mathrm{mg} / \mathrm{dL}$, cows with serum total proteins $\leq 5.0 \mathrm{mg} / \mathrm{dL}$ were 3.1 times more likely to have a 305-d lactation $>10,500$ $\mathrm{kg}$. Serum alkaline phosphatase concentrations did not evidence the presence of fatty liver, and consequently, this blood metabolite did not alter the reproductive performance of cows.

\section{Discussion}

Serum BHBA one-week postpartum was successful at discriminating between cows becoming pregnant at first service, cows requiring less than two services per pregnancy, and cows becoming pregnant before $80 \mathrm{~d}$ postpartum. Although circulating ketone bodies can be used to a certain extent as energy source by mammary tissue and other organs, excessive blood ketone bodies negatively affect the reproduction function. In line with the results of the present study, Rutherford et al. (2016) and Mellado et al. (2018b) also found that low blood BHBA levels shortly after calving had a positive effect on the establishment of pregnancy at first service. However, in the present study this metabolite was not related to conception rate to all services, which is not in line with Walsh et al. (2007) and Ospina et al. 2010) who observed higher overall conception rates in nonketotic than in ketotic cows.

Table 5. Associations of postpartum serum metabolite concentrations one week after calving with the risk of more than $10,500 \mathrm{~kg}$ of milk in 305-day lactations in high-yielding Holstein cows $(\mathrm{n}=165)$ in a hot environment. Only significant variables are presented.

\begin{tabular}{|c|c|c|c|c|c|c|c|}
\hline $\begin{array}{l}\text { Variables and area under the } \\
\text { curve (AUC) }\end{array}$ & $\begin{array}{c}\% \text { of cows }> \\
10,500 \mathrm{~kg} \\
\text { milk }\end{array}$ & $\begin{array}{l}\text { Odds ratio } \\
\text { (OR) }\end{array}$ & $\begin{array}{l}\text { OR 95\% } \\
\text { CI }\end{array}$ & $\mathbf{p}$ & Cutpoint $^{1}$ & $\begin{array}{l}\text { Sen }^{2} \\
(\%)\end{array}$ & $\begin{array}{l}\text { Spec }^{3} \\
(\%)\end{array}$ \\
\hline $\mathrm{BUN}, \mathrm{mg} / \mathrm{dL}$ & & & & 0.024 & $14.9 \mathrm{mg} / \mathrm{dL}$ & 59 & 41 \\
\hline$\leq 15 \quad \mathrm{AUC}=.60$ & $42.2(35 / 83)$ & Referent & & & & & \\
\hline$\geq 15$ & $59.8(49 / 82)$ & 2.0 & $1.1-3.7$ & & & & \\
\hline Creatinine, $\mathrm{mg} / \mathrm{dL}$ & & & & 0.0015 & $1.8 \mathrm{mg} / \mathrm{dL}$ & 67 & 47 \\
\hline$\geq 2.0 \quad \mathrm{AUC}=.66$ & $38.8(33 / 85)$ & Referent & & & & & \\
\hline$\leq 2.0$ & $63.8(51 / 80)$ & 2.8 & $1.5-5.2$ & & & & \\
\hline Total proteins, $\mathrm{mg} / \mathrm{dL}$ & & & & 0.0005 & $5.0 \mathrm{mg} / \mathrm{dL}$ & 68 & 39 \\
\hline$\geq 5.0 \quad \mathrm{AUC}=.65$ & $37.9(33 / 87)$ & Referent & & & & & \\
\hline$\leq 5.0$ & $65.4(51 / 78)$ & 3.1 & $1.6-5.8$ & & & & \\
\hline BCS change at 30 DIM & & & & 0.03 & & & \\
\hline$\leq .41 \quad \mathrm{AUC}=.60$ & $41.9(31 / 74)$ & Referent & & & & & \\
\hline$\geq .41$ & $58.2(53 / 91)$ & 1.9 & $1.1-3.6$ & & & & \\
\hline
\end{tabular}

$\mathrm{BUN}=$ blood urea nitrogen; $\mathrm{BCS}=$ body condition score; $\mathrm{AUC}=$ area under the ROC (receiver operating characteristic) curve. ${ }^{1}$ Cutpoint $=$ herd alarm level where an increased probability of 305 -d milk yield $<10,500 \mathrm{~kg}$ exists based on serum metabolite concentration in transition cows.

${ }^{2}$ Sen $=$ Epidemiologic sensitivity from a receiver operating characteristic curve.

${ }^{3} \mathrm{Spec}=$ Epidemiologic specificity from a receiver operating characteristic curve. 
This lack of difference in overall conception rate compared with previous studies seems to be because non-pregnant cows in our study were recurrently re-bred (cows were served on average 2.7 times per pregnancy), and it is likely that by the time cows received their second or third service, high serum BHBA had subsided. Most reports for postpartum blood BHBA concentration cut-points that maximize accuracy of disease prediction and production measures range from 1.2 to $1.46 \mathrm{mmol} / \mathrm{L}$ (McArt et al., 2013). It was clear in the present study that much lower levels of serum BHBA $(0.80 \mathrm{mmol} / \mathrm{L})$ one week after calving affect the reproduction function of high-yielding cows, based on increased negative effects on the reproductive performance of transition Holstein cows.

Surprisingly, serum NEFA levels did not affect the probability of pregnancy at first AI, which is not in line with other studies in lactating dairy cows (Ospina et al., 2010; Garverick et al., 2013) where the likelihood of pregnancy is reduced when blood NEFA concentrations increase postpartum. Thus, our data suggest that serum NEFA is a less efficient indicator of subsequent fertility than serum BHBA in high-yielding dairy cows during the early lactation period. This is in agreement with Duffield (2000) who stated that the use of BHBA is a better indicator of energy imbalance than NEFA in postpartum animals.

Our results also indicate that serum creatinine levels one-week postpartum can be used to distinguish cows more likely to become pregnant at first service. Creatinine formation occurs almost exclusively in the muscle and this metabolite is highly related to total body muscle mass (Costa-Silva et al., 2012; Kim et al., 2016); therefore, serum creatinine could be considered a specific index to define muscle mass. Thus, individuals with higher muscle mass present higher blood creatinine (Baxmann et al., 2008), and larger muscle mass is a reflection of a higher body condition score, which is highly related to improved reproduction function of dairy cows (López-Gatius et al., 2003; Carvalho et al., 2014).
Low BCS at 30 and 60 days postpartum had a detrimental effect on both first-service conception rate and conception rate to all services. These results are in line with other studies where BCS at 60 to $100 \mathrm{~d}$ of lactation was positively associated with pregnancy rate (Buckley et al., 2003; Gomez et al., 2018). This response may be explained because high milk yielding dairy cows use a great amount of energy to cope with the marked increase in milk yield at the beginning of lactation. This increased energy requirement is partially met by increased feed intake but at a slower rate than milk production; the remainder being met by retrieval of body energy reserves which results in cows with a NEB (Grummer, 2007). The timing of BCS loss (NEB) coincides with involution and remodeling of the uterine and oviductal structures, ovarian activity reinitiation, and, for some cows, fertilization and blastocyst and early conceptus growth. This NEB leads to decrease BCS and cows in low BCS at calving, or those suffering excess BCS loss early post-calving, are more likely to present delayed first ovulation (Shrestha et al., 2005), are less likely to ovulate, have reduced conception rate to first service and also have increased likelihood for pregnancy loss and increased calving to conception interval (Roche et al., 2009; Shin et al., 2015; Barletta et al., 2017).

In the present study, high serum BHBA concentrations were associated with higher number of services per conception, which is in line with other studies with dairy cows experiencing ketosis shortly after calving (Gillund et al., 2001; Mellado et al., 2018b). Considering AUC (0.64), blood BHBA concentrations one-week post-calving presented a moderately accurate discriminating ability for cows requiring more than two services to become pregnant. It was also found that blood glucose at the beginning of lactation is useful for defining whether a cow requires more than two services for conception. These results are in agreement with findings of Guzel and Tanriverdi (2014), who observed that repeat breeder cows had lower blood 
glucose levels compared to fertile ones. It has been considered that blood glucose has a moderate diagnostic value in the assessment of the nutritional status of cattle as it varies moderately in blood, however, in the present study, the AUC of 0.61 showed that this blood metabolite was a fair classifier to separate cows needing more than two services per pregnancy.

Cows with lower serum creatinine levels required more services to become pregnant than cows with high levels. Given that serum creatinine is a biomarker of skeletal muscle mass (Patel et al., 2013) or body weight (CostaSilva et al., 2012), cows with more intense mobilization of muscle protein (high blood creatinine concentration indicate proteolysis; McCabe and Boerman, 2020) presented decreased reproductive performance as cows with lesser muscle mass cannot optimize reproduction function (Bewley and Schutz, 2008). However, it is worth mentioning that urinary creatinine is not related to BCS in cattle (Whittet et al., 2019). Cows with high serum TP levels were also more likely to require more than two services per pregnancy. These results are difficult to explain because blood $\mathrm{TP}$ reflects the availability of protein and their level decline with protein deficiency. It could be that the major contribution of TP was from the diet, as the body has a regulatory mechanism to maintain the adequate protein levels in the serum, and high protein intake has a negative influence on services per pregnancy (Sinclair et al., 2014). Increased proteins (mainly serum albumin and immunoglobulins) in the blood of cows indicate activation of the immune response following an infection (Tothova et al., 2016); thus, it is not discarded that high serum TP could also have arisen due to mild periparturient diseases.

Serum BUN during the first week of lactation was identified as a predictive biomarker of 305$\mathrm{d}$ milk yield above $10,500 \mathrm{~kg}$ in pluriparous cows. High BUN levels could indicate a high protein intake (energy intake held constant) or the excessive mobilization of muscle. Given that cows in this study received high energy diets, it is believed that the higher milk yield of cows with high BUN was due to higher ingestion of protein. Increased solubility or degradability of dietary protein leads to increased ruminal ammonia concentrations resulting in increased BUN concentrations (Hristov et al., 2004). These results are in agreement with findings of Nozad et al. (2012), who found higher BUN levels in high-yielding dairy cows relative to low-yielding cows. Wathes et al. (2007b) also documented that blood urea is positively related to milk yield. Thus, $14.9 \mathrm{mg} / \mathrm{dL}$ serum BUN levels shortly after calving for pluriparous high milk yield is indicative of higher odds of cows to reach $305-\mathrm{d}$ milk yield $>10,500 \mathrm{~kg}$.

Serum creatinine levels lower than 1.8 $\mathrm{mg} / \mathrm{dL}$ resulted in higher proportion of cows presenting $>10,500 \mathrm{~kg}$ milk in 305-d lactations. Serum creatinine levels correlated significantly with body weight, but the level of correlation with lean mass is even greater (Baxmann et al., 2008). Low serum levels of creatinine in cows producing $>10,500 \mathrm{~kg}$ of milk evidence that cows were mobilizing high amounts of body proteins during the first weeks of lactation. Thus, these data suggest that cows with greater muscle mass had higher body energy reserves which could be used for greater milk synthesis, which resulted in 305-d milk yields $>10,500$ $\mathrm{kg}$. This was supported by the fact that cows with higher BCS changes from calving to $30 \mathrm{~d}$ post-calving (e.g. higher mobilization of body fat reserves) were more likely to present 305-d milk yield greater than $10,500 \mathrm{~kg}$ than cows with less BCS change post-calving. When milk yield is ascending at the beginning of lactation and energy requirements exceed feed intake cows experience NEB, which leads to mobilization of lipid and labile protein reserves, getting thinner, and lose BCS (Agenäs et al., 2003). In line with the results of the present study, other reports have demonstrated that cows with greater body reserve mobilization tend to produce more milk than cows with medium or low levels of body energy mobilization (Pedernera et al., 2010; Gheise et al., 2017). 
In conclusion, this study shows that high serum BHBA and low serum creatinine levels during the first week of lactation in high-yielding Holstein cows in a hot environment are negatively linked to reproductive efficiency. Further, BCS in early lactation is predictive of cows establishing pregnancy, therefore it would be useful to monitor and perhaps modify BCS during the 30-60 d after calving to optimize reproduction in high-producing Holstein cows. Additionally, high serum BUN, low creatinine, and TP, as well as a greater loss of BCS during the first month of lactation are sensitive biochemical markers to detect animals capable of producing $>10,500 \mathrm{~kg}$ milk in $305 \mathrm{~d}$ among high-yielding Holstein cows. For their greater sensitivity and specificity, blood values of BHBA can be used in early lactation to predict reproductive performance, which will not only provide new references for prediction and diagnosis of ketosis but also finds novel directions for research focussed on the connection between BHBA and reproductive variables. Serum alkaline phosphatase was not associated with any of the reproductive variables, which suggests that fatty liver was not a major metabolic disorder in these cows, and consequently did not decrease health status and reproductive performance.

\section{Declarations}

\section{Funding}

This study was supported by a grant from Universidad Autónoma Agraria Antonio Narro, Saltillo, Mexico.

\section{Conflict of interest}

The authors declare they have no conflicts of interest with regard to the work presented in this report.

\section{Author contribution}

Conceived and designed the experiments: Miguel Mellado and Edit Torres. Performed the experiment: Ulices Macías-Cruz, Edir Torres, Juan D. Hernández-Bustamante, Carlos Leyva and Francisco G. Véliz. Analyzed the data: Miguel Mellado and José E. García. Wrote the paper: Miguel Mellado. All authors of this submission revised the final version.

\section{References}

Agenäs S, Burstedt E, Holtenius K. Effects of feeding intensity during the dry period. 1 Feed intake body weight and milk production. J Dairy Sci 2003; 86(3): 870-882. DOI: http://doi.org/10.3168/jds.s0022-0302(03)73670-4

Ashworth CJ, Toma LM, Hunter MG. Nutritional effects on oocyte and embryo development in mammals: implications for reproductive efficiency and environmental sustainability. Philosoph Trans Royal Soc London Series B Biol Sci 2009; 364(1534): 3351-3361. DOI: http://doi.org/10.1098/rstb.2009.0184

Barletta RV, Maturana Filho M, Carvalho PD, Del Valle TA, Netto AS, Rennó FP, Mingoti RD, Gandra JR, Mourão GB, Fricke PM, Sartori R, Madureira EH, Wiltbank MC. Association of changes among body condition score during the transition period with NEFA and BHBA concentrations milk production fertility and health of Holstein cows. Theriogenology 2017; 104: 30-36. DOI: http://doi.org/10.1016/j.theriogenology.2017.07.030

Baxmann AC, Ahmed MS, Marques NC, Menon VB, Pereira AB, Kirsztajn GM, Heilberg IP. Influence of muscle mass and physical activity on serum and urinary creatinine and serum cystatin. C. Clin J Am Soc Nephrol 2008; 3(2): 348-354. DOI: http://doi.org/10.2215/CJN.02870707

Bewley JM, Schutz MM. Review: an interdisciplinary review of body condition scoring for dairy cattle. Profess Anim Sci 2008; 24(6): 507-529. DOI: http://doi.org/10.15232/s1080-7446(15)30901-3

Buckley F, O'Sullivan K, Mee JF, Evans RD, Dillon P. Relationships among milk yield body condition cow weight and reproduction in spring-calving Holstein Fresians. J Dairy Sci 2003; 86(7): 2308-2319. DOI: http://doi.org/10.3168/jds.s0022-0302(03)73823-5 
Butler WR. Energy balance relationships with follicular development ovulation and fertility in postpartum dairy cows. Livest Prod Sci 2003; 83(2-3): 211-218. DOI: http://doi.org/10.1016/S0301-6226(03)00112-X

Carvalho PD, Souza AH, Amundson MC, Hackbart KS, Fuenzalida MJ, Herlihy MM, Ayres H, DreschAR, Vieira LM, Guenther JN, Grummer RR, Fricke PM, Shaver RD. Relationships between fertility and postpartum changes in body condition and body weight in lactating dairy cows. J Dairy Sci 2014; 97(6): 3666-3683. DOI: http://doi.org/10.3168/jds.2013-7809

Costa-Silva LF, de Campos Valadares Filho S, Chizzotti ML, Rotta PP, Prados LF, Valadares RFD, Zanetti D, da Silva Braga JM. Creatinine excretion and relationship with body weight of Nellore cattle. Rev Bras Zoot 2012; 41(3): 807-810. DOI: https://doi.org/10.1590/S1516-35982012000300046

Duffield T. Subclinical ketosis in lactating dairy cattle. Vet Clin North Am Food Anim Pract 2000; 16(2): 231-253. DOI: http://doi.org/10.1016/S0749-0720(15)30103-1

FASS. Guide for the care and use of agricultural animals in agricultural research and teaching Federation of Animal Science Societies Champaign IL USA. 2010.

Garverick HA, Harris MN, Vogel-Bluel R, Sampson JD, Bader J, Lamberson WR, Spain JN, Lucy MC, Youngquist RS. Concentrations of nonesterified fatty acids and glucose in blood of periparturient dairy cows are indicative of pregnancy success at first insemination. J Dairy Sci 2013; 96(1): 181-188. DOI: http://doi.org/10.3168/jds.2012-5619

Gheise NJE, Riasi A, Zare Shahneh A, Celi P, Ghoreishi SM. Effect of pre-calving body condition score and previous lactation on BCS change blood metabolites oxidative stress and milk production in Holstein dairy cows. Italian J Anim Sci 2017; 16(3): 474-483. DOI: http://doi.org/10.1080/1828051X.2017.1290507
Gillund P, Reksen O, Gröhn YT, Karlberg $\mathrm{K}$. Body condition related to ketosis and reproductive performance in Norwegian dairy cows. J Dairy Sci 2001; 84(6): 1390-1396. DOI: https://doi.org/10.3168/jds.s0022-0302(01)70170-1

Gomez NA, Conley AJ, Robinson PH. Effects of long-term near-term and real-time energybalance and blood progesterone concentrations on the pregnancy rate of contemporary dairy cows. Anim Reprod Sci 2018; 189(1): 136-145. DOI: http://doi.org/10.1016/j.anireprosci.2018.01.001

Grummer RR, Mashek DG, Hayirli A. Dry matter intake and energy balance in the transition period. Vet Clin North Am Food Anim Prac 2004; 20(3): 447-470. DOI: http://doi.org/10.1016/j.cvfa.2004.06.013

Grummer RR. Strategies to improve fertility of high yielding dairy farms: management of the dry period. Theriogenology 2007; 68(1): S281-S288. DOI: http://doi.org/10.1016/j.theriogenology.2007.04.031

Guzel S, Tanriverdi M. Comparison of serum leptin glucose total cholesterol and total protein levels in fertile and repeat breeder cows. Rev Bras Zoot 2014; 43(12): 643-647. DOI: http://doi.org/10.1590/S1516-35982014001200003

Hristov AN, Etter RP, Ropp JK, Grandeen KL. Effect of dietary crude protein level and degradability on ruminal fermentation and nitrogen utilization in lactating dairy cows. J Anim Sci 2004; 82(11): 3219-3229. DOI: http://doi.org/10.2527/2004.82113219x

Kim SW, Jung HW, Kim CH, Kim KIl, Chin HJ, Lee H. A new equation to estimate muscle mass from creatinine and cystatin C. PLoS ONE 2016; 11(2): e0148495. DOI: https://doi.org/10.1371/journal.pone.0148495

Leroy JL, Van holder T, Van Knegsel ATM, Garcia-Ispierto I, Bols PEJ. Nutrient prioritization in dairy cows early postpartum: mismatch between metabolism and fertility? Reprod DomestAnim 2008; 43(2): 96-103. DOI: https://doi.org/10.1111/j.1439-0531.2008.01148.x 
López-Gatius F, Yániz J, MadrilesHelm D. Effects of body condition score and score change on the reproductive performance of dairy cows: A meta-analysis. Theriogenology 2003; 59(3-4): 801-812. DOI: http://doi.org/10.1016/S0093-691X(02)01156-1

McArt JAA, Nydam DV, Oetzel GR, Overton TR, Ospina, PA. Elevated non-esterified fatty acids and $\beta$-hydroxybutyrate and their association with transition dairy cow performance. Vet J 2013; 198(3): 560-570. DOI: http://doi.org/10.1016/j.tvj1.2013.08.011

McCabe CJ, Boerman JP. Invited Review: Quantifying protein mobilization in dairy cows during the transition period. Appl Anim Sci 2020; 36(3): 389-396. DOI: https://doi.org/10.15232/aas.2019-01929

Mellado M, García JE, Véliz Deras FG, de Santiago MA, Mellado J, Gaytán LR, Ángel-García O. The effects of periparturient events mastitis lameness and ketosis on reproductive performance of Holstein cows in a hot environment. Austral J Vet Sci 2018a; 50(1): 1-8. DOI: http://doi.org/10.4067/s0719$\underline{81322018000100102}$

Mellado M, Dávila A, Gaytán L, Macías-Cruz U, Avendaño-Reyes L, García JE. Risk factors for clinical ketosis and association with milk production and reproduction variables in dairy cows in a hot environment. Trop Anim Health Prod 2018b; 50(7): 1611-1616. DOI: http://doi.org/10.1007/s11250-018-1602-y

Nozad S, Ramin AG, Moghadam G, Asri-Rezaei S, Babapour A, Ramin S. Relationship between blood urea protein creatinine triglycerides and macro-mineral concentrations with the quality and quantity of milk in dairy Holstein cows. Vet Res Forum 2012; 3(1): 55-59. DOI: http://www.ncbi.nlm.nih.gov/pmc/articles/ $\underline{\mathrm{PMC} 4312820 /}$

NRC. National Research Council. Nutrient Requirements of Dairy Cattle 7th ed Washington DC National Academic Press. 2001.
Oikonomou G, Arsenos G, Valergakis GE, Tsiaras A, Zygoyiannis D, Banos G. Genetic relationship of body energy and blood metabolites with reproduction in Holstein cows. J Dairy Sci 2008; 91(11): 4323-4332. DOI: http://doi.org/10.3168/jds.2008-1018

Ospina PA, Nydam DV, Stokol T, Overton TR. Associations of elevated nonesterified fatty acids and $\beta$-hydroxybutyrate concentrations with early lactation reproductive performance and milk production in transition dairy cattle in the northeastern United States. J Dairy Sci 2010; 93(4): 1596-1603. DOI: http://doi.org/10.3168/jds.2009-2852

Patel SS, Molnar MZ, Tayek JA, Ix JH, Noori N, Benner D, Heymsfield S, Kopple J, D, Kovesdy CP, Kalantar-Zadeh K. Serum creatinine as a marker of muscle mass in chronic kidney disease: Results of a cross-sectional study and review of literature. J Cachexia Sarcop Muscle 2013; 4(1): 19-29. DOI: http://doi.org/10.1007/s13539-012-0079-1

Pedernera M, Celi P, Garci SC, Salvin HE, Barchia I, Fulkerson WJ. Effect of diet energy balance and milk production on oxidative stress in early-lactating dairy cows grazing pasture. Vet J 2010; 186(3): 352-357. DOI: http://doi.org/10.1016/j.tvj1.2009.09.003

Pires JAA, Delavaud C, Faulconnier Y, Pomiès D, Chilliard Y. Effects of body condition score at calving on indicators of fat and protein mobilization of periparturient Holstein-Friesian cows. J Dairy Sci 2013; 96(10): 6423-6439. DOI: http://doi.org/10.3168/jds.2013-6801

Roche JR, Friggens NC, Kay JK, Fisher MW, Stafford KJ, Berry DP. Invited review: body condition score and its association with dairy cow productivity health and welfare. J Dairy Sci 2009; 92(12): 5769-5801. DOI: http://doi.org/10.3168/jds.2009-2431 
Roche JR, Burke CR, Crookenden MA, Heiser A, Loor JL, Meier S, Mitchell MD, Phyn CVC, Turner SA. Fertility and the transition dairy cow. Reprod Fert Develop 2017; 30(1): 85-100. DOI: http://doi.org/10.1071/rd17412

Rutherford AJ, Oikonomou G, Smith RF. The effect of subclinical ketosis on activity at estrus and reproductive performance in dairy cattle. J Dairy Sci 2016; 99(6): 4808-4815. DOI: http://doi.org/10.3168/jds.2015-10154

Santos JEP, Rutigliano HM, Sa Filho MF. Risk factors forresumptionofpostpartumestrouscycles and embryonic survival in lactating dairy cows. Anim Reprod Sci2009; 110(3-4): 207-221. DOI: http://doi.org/10.1016/j.anireprosci.2008.01.014

SAS/STAT Software. Version 9.4, SAS Institute Inc., Cary, NC, USA; 2016.

Shin EK, Jeong JK, Choi IS, Kang HG, Hur TY, Jung YH, Kim IH. Relationships among ketosis serum metabolites body condition and reproductive outcomes in dairy cows. Theriogenology 2015; 84(2): 252-260. DOI: http://doi.org/10.1016/j.theriogenology.2015.03.014

Shrestha HK, Nakao T, Suzuki T, Akita M, Higaki T. Relationships between body condition score body weight and some nutritional parameters in plasma and resumption of ovarian cyclicity postpartum during pre-service period in high-producing dairy cows in a subtropical region in Japan. Theriogenology 2005(4); 64: 855-866. DOI: http://doi.org/10.1016/j.theriogenology.2004.12.007

Sinclair KD, Garnsworthy PC, Mann GE, Sinclair LA. Reducing dietary protein in dairy cow diets: Implications for nitrogen utilization milk production welfare and fertility. Animal 2014; 82(2): 262-274. DOI: http://doi.org/10.1017/s1751731113002139
Tothova C, Nagy O, Kovac G. Serum proteins and their diagnostic utility in veterinary medicine: a review. Vet Med 2016; 619(9): 475-496. DOI: http://doi.org/10.17221/19/2016-VETMED

Van Hoeck V, Bols PEJ, Binelli M, Leroy JLMR. Reduced oocyte and embryo quality in response to elevated non-esterified fatty acid concentrations: A possible pathway to subfertility? Anim Reprod Sci 2014; 149(1-2): 19-29. DOI: http://doi.org/10.1016/j.anireprosci.2014.07.015

Walsh RB, Walton JS, Kelton DF, LeBlanc SJ, Leslie KE, Duffield TF. The effect of subclinical ketosis in early lactation on reproductive performance of postpartum dairy cows. J Dairy Sci 2007; 90(6): 2788-2796. DOI: http://doi.org/10.3168/jds.2006-560

Wathes DC, Cheng Z, Bourne N, Taylor VJ, Coffey MP, Brotherstone S. Differences between primiparous and multiparous dairy cows in the inter-relationships between metabolic traits milk yield and body condition score in the periparturient period. Dom Anim Endocrinol 2007a; 33(2): 203-225. DOI: http://doi.org/10.1016/j.domaniend.2006.05.004

Wathes DC, Fenwick M, Cheng Z, Bourne N, Llewellyn S, Morris DG, Kenny D, Murphy J, Fitzpatrick R. Influence of negative energy balance on cyclicity and fertility in the high producing dairy cow. Theriogenology 2007b; 68(1): 232-241. DOI: http://doi.org/10.1016/j.theriogenology.2007.04.006

Whittet KM, Watson AK, Erickson GE, Klopfenstein TJ. Factors affecting urinary creatinine in heifers and cows. Translat Anim Sci 2019; 3(1): 532-540. DOI: https://doi.org/10.1093/tas/txz004 